\title{
APPLICABILITY OF COMMUNITY PROPERTY LAWS TO NATIONAL SERVICE LIFE: INSURANCE
}

In California, a commercial life insurance policy, purchased with community funds, is a community asset, ${ }^{1}$ the proceeds of which are community property. ${ }^{2}$ But in the leading case of Wissner v. Wissner, ${ }^{3}$ the United States Supreme Court strongly indicated that proceeds of a National Service Life Insurance policy ${ }^{4}$ could not, consonant with congressional intent, be community property. ${ }^{5}$ However, any

1 In re Castagnola's Estate, 68 Cal. App. 732, 230 Pac. 188 (1924). Unless otherwise specified all discussion will assume a policy on the life of a husband, the premiums for which have been paid with commumity funds.

2 When premiums are paid with both separate and community funds, proceeds are separato and community in proportion to the amount of each type used. McBride v. McBride, $11 \mathrm{Cal}$. App. 2d 521, 54 P.2d 480 (1936). This rule does not obtain in all community jurisdictions. Sce Succession of Lewis, 192 La. 734, 189 So. 118 (1939). For a review of the life insurance community property laws of these states, see Huie, Community Property Laws as Applied to Life Instrance. 17 TEXAS L. Rev. 121 (1939), 18 id. 121 (1940).

3338 U.S. 655 (1950).

438 U.S.C.A. $\$ \S 701-24$ (Supp. 1959) [hereinafter referred to as "NSLI"]. The NSLI Act of 1940, 54 Stat. 1008, as amended, was repealed incident to the consolidation of all laws administered by the Veterans' Administration and re-enacted into positive law as part of Title 38, United States Code, "Veterans' Benefits," by the Act of Siptember 2, 1958, 72 Stat. 1105, effective January 1, 1959.

This note primarily treats post-war "Participating (dividend-sharing) NSLI" and its wartime ancestor, many aspects of which are similar or identical to other veterans' insurance schemes, of which there presently are four: (1) Particifating NSLI, as of 1956, represented approximately $84 \%$ of all veterans' insurance in force, having 5.5 million members with a total of $\$ 35.9$ billion face value insurance. It liad its inception in World War II NSLI. (For specific characteristics of the wartime and post-war forms, see text of notes 15-33 infra). It closed to new issues April 25, 1951. (2) United States Government Iife Insurance (USGLI), 38 U.S.C.A. \$ 740-60 (Supp. 1959), had its inception in World War I War Risk Insurance and is participating. It closed to new issues in 1951. (3) Veterans' Special Term Instrance, 38 U.S.C.A. \$ 723 (Supp. 1959) (old NSLI Act \$ 621), issued after 1951, had its inception in Servicemen's Free Indemnity Insurance for Korean servicemen and closed to new issues January 1, 1957. It was non-participating, non-convertible five-year renewable NSLI Term insurance; however, by the Act of September 2, 1958, 72 Stat. 1105 (Public Law 85-896) this insurance was made convertible to non-participating permanent NSLI plans. 38 U.S.C.A. $\$$ 723(b) (Supp. 1959). (4) Service Disabled Veterans Insurance, 38 U.S.C.A. \& 722 (Supp. 1959) (old NSLI Act $\S 620$ ), was made available after 1951 and modified slightly in 1958, and is non-participating. A veteran who applys within a certain period after a service-connected disability as establislied by the Veterans' Administration is eligible; he may apply thereafter for a non-participating permanent NSLI plan.

See Administrator of Veterans Affairs Annual Report for Fiscal Year 1956, H.R. Doc. No, 8, 85th Cong., 2d Sess., 130-32, 278 (1957) [hereinafter cited as the 1956 VA Report]; KruBROUGH \& GLEN, AMERICAN LAW OF VETERANS \$ 418 (2d ed. 1954).

5 In Wissner, the serviceman had substituted his mother for his wife as NSLI beneficiary shortly before his death. In ler action against the mother for oule-half of the proceeds, the wife relied upon California community property law relating to life insurance, under which she clearly would have prevailed liad this been a commercial policy.

As owner of a commercial policy on her husband's life, a wife in California has a vested right to one-half of its proceeds, even though her insured lrusband has the contractual power to designate and change beneficiaries. Dixon Lumber Co. v. Peacock, $217 \mathrm{Cal}, 415,19$ P.2d 233 (1933). As his named beneficiary she obtains a co-existent but distinguishable "expectancy" as the object of a defeasible gift of lis one-half share. This becomes absolute upon his denth if she remains his beneficiary. Grimm v. Grimm, 26 Cal.2d 173, 157 P.2d 841 (1945); Evans, Some Secondary Sources of Acquisition of Community Property, 11 C.Irr. L. REv. 156, 157 (1923). For beneficiaries' rights, see generally VANCE, Insurance 656-67 (3d ed. 1951). Thus, even where lie designates a third party the husband may not give away the wife's one-half, and she 
broad implication of Wissner that NSLI proceeds are completely immune from community property law doctrines was rejected in the recent case of Estate of Allie $^{0}$ by a unanimous California Supreme Court.

In Allie, NSLI policy premiums were paid with community funds, and the insured husband designated his wife as beneficiary. The husband died in 1956, and upon the wife's death one month later, intestate and without surviving spouse or issue, the proceeds were paid to her estate. Sisters of the husband then sought to establish a right to one-half of the proceeds under California Probate Code section 228.7 Their claim was contested by the wife's brother who asserted a right to all of the proceeds under Probate Code section 225. ${ }^{\circ}$ The brother contended that since community property status was essential to the operation of section 228 , Wissner automatically precluded that section froln applying.

The supreme court denied this contention and ordered the proceeds distributed in accordance with section 228. The court determined that Wissner forestalled community property claims only when they would disturb a distribution that had been specifically ordered by the insured. That is, conflict with the NSLI Act arises only when the insured's named beneficiary will not take all of the proceeds under community property laws or where those laws conflict with the named beneficiary's express choice of disposal. ${ }^{9}$ Since in Allie the insured's chosen beneficiary did receive all of the proceeds, and since she died without specifically indicating to whom she wished them paid, the court reasoned that it was not compelled by the NSLI Act to insulate the federal funds from community claims in this situation and, therefore, local property laws were applicable.

In reaching its decision, the court did not assign a California marital property classification to the proceeds or to the policy. The court reasoned that since the property character of the traceable initial source of the proceeds during the marriage controls distribution of an estate under section 228 and its separate property companion section $229,{ }^{10}$ and since in this situation the proceeds were traceable

may sue to recover it in her own right. Travelers Ins. Co. v. Fancher, 219 Cal. 351, 353, 26 P.2d 482,483 (1933). However, a beneficiary who gives value takes free of the wife's claims due to the power of the husband to transfer community property for consideration. Union Mutual Life Ins. Co. v. Broderick, $196 \mathrm{Cal}$. 497, 507-08, 238 Pac. 1034, 1038 (1925) (alternative holding). See Cax. Crv. Code $\$ 172$.

The Wissner Court, 5-3, held these principles inapplicable to NSLI by finding that Congress intended to confer upon all servicemen the right, limited only by specific provisions of the act, to dispose of the proceeds as they saw fit.

6 $50 \mathrm{Cal} .2 \mathrm{~d} 794,329$ P.2d 903 (1958).

7 CAL. PROB. CODE $\$ 228$, as applicable here, reads: "If the decedent leaves neither spouse nor issue, and the estate or any portion thereof was community property of the decedent and a previously deceased spouse, and belonged or went to the decedent by virtue of its commumity character on the death of such spouse, or came to the decedent from said spouse by gift, descent, devise or bequest ... then one-half of such community property goes ... in equal shares to the [heirs of] ... the decedent . . . and the other half .. in equal shares to the [heirs of] ... said [previously] deceased spouse. . .."

8 CAL. PROB. CODE $\$ 225$, applying to intestate distribution of separate property and as applicable here, reads: "If the decedent leaves neither issue nor spouse, the estate goes to his parents in equal shares, or if either is dead, to the survivor, or if both are dead in equal shares to his brothers and sisters ...."

9 See text at notes 22-24, 33 infra, for the particular provisions held to be controlling in Wissner, an analysis of which led the court in Allie to delimit the conflict between the NSLI statute and community property laws.

10 Estate of Abdale, 28 Cal.2d 587, 590-92, 170 P.2d 918, 920-21 (1946). Sections 228 and 229 must be construed together. In the Matter of Estate of Rattray, 13 Cal.2d 702, 712-15, 91 P.2d 1042, 1048-49 (1939). The theory of these sections is that the decedent's property 
back to the community funds used for premiums, section 228 prescribed the proper method of distribution.

It appears that it was unnecessary for the court to have classified the policy or the proceeds as community property. In fact, the particular holding in Allie relating to section 228 seems entirely consistent with a characterization of NSLI policies and proceeds as the husband's "separate property." A lusband and wife in California may transmute informally the character of their property inter se. ${ }^{11}$ Where section 228 or 229 may be applicable, however, the "initial source" rule still determines distribution, irrespective of interim transmutations. ${ }^{12}$ Thus, if a wife releases to her husband her community ownership rights in a policy, it will be his separate property at his death. If she receives the proceeds as his designated beneficiary, and subsequently dies intestate without surviving issue or spouse, section 228 would apply, the separate property character of the policy at the husband's death being disregarded in favor of the prior community property character of the premiums. ${ }^{13}$

If proceeds of a commercial policy had been involved in Allie, the court doubtless would have classified the policy as having been community property. The court probably would have reasoned that the wife took one-half of the proceeds in her own community right and one-half by virtue of a gift by the husband of his community share, and concluded that this community property nature would be preserved for the purpose of applying section $228 .{ }^{14}$ The reason the court did not, and perhaps could not, analyze the issue in this manner hinges upon the apparent impossibility of directly referring to NSLI policies or proceeds as community property. The following review of NSLI enactments and interpretative decisions, with

should revert to the family of the spouse initially responsible for its acquisition, or to both families if the estate is attributable to an initial community origin. See 34 Carrr. L. REv. 766 (1946).

11 Tomaier v. Tomaier, 23 Cal.2d 754, 146 P.2d 905 (1944); Perkins v. Sunset Tel. and Tel. Co., 155 Cal. 712, 719-20, 103 Pac. 190, 194 (1909).

12 There are several limitations on an operation of the "initial source" rule: (1) The party asserting application of $\S \S 228$ or 229 has the burden of tracing the estate to the claimed property source (In the Matter of Estate of Harris, 9 Cal. 2d 649, 662, 72 P.2d 873, 880 (1937)); (2) the estate is not traceable beyond a property character transmutation which occurred pursuant to an inter-spouse agreement supported by valuable consideration (Estate of Hobart, 82 Cal. App. 2d 502, 506, 187 P.2d 105, 109 (1947)); (3) a "new title" in decedent -i.e., where the surviving spouse reacquires property transferred to a third party-will bar the operation of $\S \S 228$ and 229 altogether (see Estate of Flood, 55 Cal. App. 2d 410, 130 P.2d 811 (1942)).

13 Estate of Abdale, 28 Cal. 2d 587, 170 P.2d 918 (1946); In the Matter of Estate of Slack, 13 Cal. 2d 721, 91 P.2d 1052 (1939). No case on these precise facts has been found. Though the Abdale and Slack cases also were concerned with co-tenancy problems, they clearly espouse the proposition that the character of the property upon its initial acquisition, not upon the death of the predeceased spouse, is controlling. See also Estate of Taitmeyer, 60 Cal. App. 2d 699, 141 P.2d 504 (1943).

14 No case relying for a holding on this precise analysis has been found. Rather, the courts usually speak of the mode by which the wife, as beneficiary, takes the proceeds of a community policy, as a gift of the whole amount from the husband. See e.g., Estate of Perkins, 21 Cal. 2d 561, 571, 134 P.2d 231, 237 (1943). Cf. In the Matter of Estate of Miller, 23 Cal. App. 2d 16, 18, 71 P.2d 1117 (1937), subsequently overruled by In the Matter of Estate of Rattray, 13 Cal. 2d 702, 91 P.2d 1042 (1939), on the broider ground that transmutation by gift does not affect the operation of $\$ \$ 228$ and 229 . Whether the "gift-of-the-whole" analysis also was disapproved is unclear. See id. at 715-16, $91 \mathrm{P} .2 \mathrm{~d}$ at 1049-50. On theory it is difficult to see low the husband can make a gift to his wife of the one-half of the proceeds to which she already has a vested right. 
particular emphasis on the Wissner case, should reveal the nature of this difficulty.

A NSLI policy, in form a contract with the Government, ${ }^{15}$ is a creature of federal statute. Riglits in it are determined solely by federal law interpreting the intent of Congress. ${ }^{16}$ NSLI originated in 1940 for World War II servicemen and was radically revised in 1946 to improve its attractiveness to veterans. ${ }^{17} \mathrm{De}$ cisions construing post-war NSLI are influenced by opinions concerning all veterans' insurance as well as the wartime NSLI form. ${ }^{18}$ Accordingly, modern NSLI should be viewed in its historical setting, even though, as will be discussed later, the precedent value of some of the cases is subject to criticism.

The scope of a NSLI insured's choice of beneficiaries, now unrestricted, was narrowly circumscribed during World War $\Pi{ }^{19} \mathrm{Me}$ has always been given the power to change beneficiaries; ${ }^{20}$ this power has been held to be absolutely irrevocable and not subject to waiver by the insured or defeasance from any source.21 This severe interpretation of an otherwise standard revocable beneficiary provision was the keystone of the Wissner decision. ${ }^{22}$ That case, which dealt with a policy

16 NSLI follows the general rule that a contract made by or with the Government is controlled by federal law. United States v. Zazove, 334 U.S. 602, 610 (1948). Cf. Clearfield Trust Co. v. United States, 318 U.S. 363, 367 (1943).

16 United States v. Foulger, 249 F.2d 237, 240 (10th Cir. 1957) ; Simmons v. United States, 120 F. Supp. 641, 646 (M.D. Pa. 1954). Ordinary principles respecting commercial insurance are said to be not controlling. See United States v. Law, 299 Fed. 61, 65 (9th Cir. 1924), rev'd on other grounds, 266 U.S. 494 (1925) (construing earlier veterans' insurance). But cf. United States v. Morrell, 204 F.2d 490, 493-94 (4th Cir. 1953) (questioning whether veterans' insurance should be treated as completely sui generis).

17 The Act of August 1, 1946, 60 Stat. 781, amending the NSLI Act of 1940, 54 Stat. 1008. The effect of this amendinent, with a few minor changes to date, is reffected in 38 U.S.C.A. $\$ \S$ 716-17 (Supp. 1959). Where used, "post-war NSLI" will refer to after-service participating NSLI dating from this amendment.

18 KMIBRouger \& GLEN, AMTERICAN LAW OF Veterans $\$ \$ 418-20$ (2d ed. 1954).

19 Compare 38 U.S.C.A. $\$ 716$ (b) (Supp. 1959), with 38 U.S.C.A. § 717(a) (Supp. 1959). The Governnent pays for all war-hazard liabilities incurred. Inasmuch as this was the predominent type of risk during the war, the Government essentially underwrote the entire program. Congress accordingly restricted the class of permissible beneficiaries to those to whom it felt the insured owed a moral duty of protection. Upon cessation of lostilities this reason for restricting his choice vanished. See Hearings on H.R. 4965 (rev. and later H.R. 5773) and H.R. 2379 (rev. and later H.R. 5772) Before the House Committee on World War Veterans' Legislation, 79th Cong., 2d Sess. 6 (1946) [hereinafter cited as the 1946 NSLI Hearings], testimony of General Omar N. Bradley, the then Administrator of Veterans' Affairs.

20 Compare 38 U.S.C.A. \& 717(a) (Supp. 1959), with the NSLI Act of 1940, ch. 757, \& $602(\mathrm{~g}), 54$ Stat. 1010.

21 See Heifner v. Soderstron, 134 F. Supp. 174 (N.D. Iowa 1955), where a Califormia divorce decree awarding the wife of a veteran all of the community property, which purportedly included a NSLI policy of which the wife previously had been beneficiary, was held to be ineffectual to support her claim to any of the proceeds as against her deceased husband's mother, wbon he had substituted as a beneficiary after commencement of the wife's divorce action. The federal court, in fact, treats the California award as though it had been one for permanent alimony rather than pursuant to a property division. See id. at 176, 179 .

More extreme are holdings that a promise by the husband, incident to a voluntary property settlement agreement, to designate a certain person and waive his right to change designation, is void ab initio. Eldin v. United States, 157 F. Supp. 34 (S.D. Ill. 1957) ; Kauffman v. Kauffman, 93 Cal. App. 2d 808, 210 P.2d 29 (1949).

22338 U.S. $655,658-59$ (1950). The Court reasoned that if the insured designates his mother he obviously wishes to exelude his wife completely. The right to name and change beneficiaries, conferred upon him by the act, was felt to be a mandate from Congress that the soldier's manifested wish nuust be protected. The wife's claim was regarded as being tantamount to an attempt by her to be interposed as a beneficiary, contrary to her husband's wishes. 
maturing in 1945, has been followed by post-war cases involving a community property-NSLI issue. ${ }^{23}$

While no property rights could "vest" in a wartime NSLI policy or its proceeds, this restriction was removed in $1946 .{ }^{24}$ Proceeds were payable during the war only to hiving persons, ${ }^{25}$ but are now payable to estates, ${ }^{26}$ including that of an insured. ${ }^{27}$ Assignment of the policy by the insured has always been prohibited. ${ }^{28}$

NSLI was originally issued as five-year term insurance. It was convertible to several standard plans, but allowed only installment settlements. ${ }^{20}$ After the war more commercial-type permanent plans were made available $e^{30}$ and the insured was empowered to provide his beneficiary witl the option of selecting a lump sum settlement. 31

NSLI avails, like most veterans' benefits, have always been exempt from taxa-

23 See e.g., Heifner v. Soderstrom, 134 F. Supp. 174, 179 (N.D. Iowa 1955). See also Eldin v. United States, 157 F. Supp. 34, 37 (S.D. Ill. 1957). An adherence to Wissner on this point is understandable since this provision was carried over unchanged from the wartime act. Its impact in the changed context should be re-examimed, however. See text at notes 51-52 infra.

24 Prior to 1946: The NSLI Act of 1940, ch. 757, $\$ 802$ (i)-(j), 54 Stat. 1010 (now 38 U.S.C.A. $\$ \$ 716$ (d)-(e) (Supp. 1959)). The 1946 Amendment: The Act of August 1, 1946, ch. $728, \S 5$ (b), 60 Stat. 783 .

See Lynch v. United States, 292 U.S. 571 (1934) (construing, earlier veterans' after-service insurance act), where it was held that the insured had a vested property right such that Congress, in contemplation of the fifth amendment, could not deny previously conferred policy rights without also denying the attendant remedy. The Wissner case, passing on World War II NSLI, held, as a ground for its decision, that the lack of vested rights in that insurance precluded the wife from developing a due process issue. (338 U.S. at 661). It would seem that the provision prohibiting vested rights presented the only persuasive ground for holding against the wife in Wissner. If the insured husband was denied "vested rights"-lue could not assign the pohicy or designate his estate-a fortiori, the wife should be prohibited from claiming as an "owner." Quaere, whether the converse of the argument in Wissner is true: i.e., whether the fact of the "vesting" of rights by the 1946 amendment afiords a good ground for a due process argument regarding denial of community property rights in post-war NSLI?

2538 U.S.C.A. $\$ 716$ (d) -(e) (Supp. 1959). When there were no surviving beneficiaries of the class, unpaid proceeds inured to the benefit of the Government. See United States v. Henning, 344 U.S. 66, 72-76 (1952). Under some circumstances unpaid proceeds might have inured to the estate of an insured who had owned a converted policy. See 38 U.S.C.A. § 716(e) (Supp. 1959).

2638 U.S.C.A. $\S 717$ (d) (Supp. 1959). Funds are payable to the estate of a beneficiary only if the insured has provided that he may select a lump-sum settlement. See KorraovorI \& GIEN, AMERTCAN LAW OF Veterans § 489 (2d ed. 1954).

27 Proceeds are payable to the insured's estate when: (1) The insured has so designated; (2) no beneficiary is designated, or the designated beneficiary does not survive the insured; (3) a designated beneficiary entitled only to an installment settlement survives the insured, but dies before receiving all sums due and payable. 38 U.S.C.A. § 117 (d) (Supp. 1959). If a contingent beneficiary is named, his rights cut across the above provisions. United States v. Short, 240 F.2d 292 (9th Cir. 1956).

2838 U.S.C.A. § 3101 (a) (Supp. 1959). The beneficiary may now assign his interest to one of those who comprise a limited class of the insured's close relations. 38 U.S.C.A. $\S 718$ (Supp. 1959).

28 The NSLI Act of 1940 , ch. 757, \& 602(f), (h), 54 Stat. 1009. The plans ineluded ordinary, twenty-payment and thirty-payment life, with provisions for loan, cash, paid-up and extended insurance values. These features carried over after 1946. See 38 U.S.C.A. § 706 (Supp. 1959).

30 The 1946 amendment added the following permanent plans: (1) twenty-year endowment; (2) endowment at age 60; (3) endowment at age 65. Sce 38 U.S.C.A. § 704 (Supp. 1959).

$$
\text { 31 } 38 \text { U.S.C.A. \& } 717 \text { (b) (1) (Supp. 1959). }
$$


tion, the claims of creditors and other similar demands. ${ }^{32}$ The Wissner Court, by analogizing the wife's community property claim to a lienor's "seizure," relied upon this provision to protect the proceeds from an insured's wife after they had been paid to the beneficiary. ${ }^{33}$

On the basis of the federal statute and interpretative decisional law prior to the Allie case, the conclusion seems irresistible that a post-war NSLI policy, which on its face has most of the characteristics of a commercial policy, should nevertheless be regarded as having been the insured husband's separate property. ${ }^{34}$ In contemplation of the insured husband's absolute power to divest his wife of any interest by merely naming as a recipient a stranger to the community, it would appear that the wife may acquire an ownership right in the proceeds only by surviving her husband as his designated beneficiary.

As noted above, the holding in Allie, limited to its special section 228 intestacy situation, is not inconsistent with this apparent "separate property" character, since a classification of proceeds was unnecessary to the decision. The Allie case, however, portends intestacy situations in which it will be necessary to a proper distribution to assign to NSLI monies a property classification. For example, assume that the insured husband designates his own estate as beneficiary ${ }^{35}$ and thereafter predeceases his wife intestate. If the wife is to receive the proceeds as community property she must take under Probate Code section $201 .^{36}$ Section 228 and the "mitial source" rule would be inapposite. Under section 201 the surviving spouse takes one-half of the community property as owner and one-half as her husband's heir. It could be argued, therefore, that since the wife could not have claimed a community ownership interest in the NSLI policy prior to her husband's death, or in the proceeds if he had left a willi ${ }^{37}$ or otherwise expressly disposed of

82 Compare the NSLI Act of $1940, \mathrm{ch} .757, \$ 616,54$ Stat. 1014 (incorporating by reference the Act of August 12, 1935, ch. 510, § 3, 49 Stat. 609 (exemption amendment to the World War Veterans' Relief Act of 1924)), with 38 U.S.C.A. § 3101 (Supp. 1959). This provision generally exempts all nonies paid to veterans. The exemption section (\$3101) now is not specifically referred to in the insurance chapter of 38 U.S.C.

83338 U.S. 655, 659 (1950). Though some early cases left the point open, this section las been held to preciude the imposition of a constructive trust on the proceeds in the hands of the beneficiary. Heifner v. Soderstrom, 134 F. Supp. 174, 181-83 (N.D. Iowa 1955). But see Voclkel v. Tohulka, 236 Ind. 588, 141 N.E.2d 344, cert. deried, 355 U.S. 891 (1957) (constructive trust impressed to effect intent of insured).

341 Ararstrong, CaItrornta FanmLY Law 523 (1953), where the author reaches this result in a comment on Wissner. Professor Armstrong was later persuaded by Estate of Perrynian, 133 Cal. App. 2d 1, 283 P.2d 298 (1955), that the sounder view was that NSLI proceeds followed normal community property rules except as otherwise required by the federal enactunent. 1 Ararstrong, op. cit. supro at 523 (Supp. 1956). Perryman is discussed at notes 42-43 infra.

35 See note 27 supra and acconpanying text.

38 CAL. Prob. CoDE $\S 201$, as applicable here, reads: "Upon the death of either husband or wife, one-half of the community property belongs to the surviving spouse; the other half is subject to the testamentary disposition of the decedent and in the absence thereof goes to the surviving spouse.... (Emphasis added).

37 It seems clear that a testate insured's specific legatees of NSLI proceeds would receive protection under Wissner from community property claims just as though they had been named policy beneficiaries. However, here the argument is weaker than in Wissner. The revocable beneficiary provision would not necessarily be thwarted since the wife would not object to payinent of the proceeds to her husband's estate by the Government and would not be "substituting herself" as a named policy beneficiary. However, proceeds in the insured's estate were held exempt from taxation under the provision discussed at note 32 supra. In re Estate of Beall, $384 \mathrm{~Pa} .14,119$ A.2d 216 (1956). By analogy, the Wissner reasoning would protect the specific legatees if the wife's assertion of community property ownership is still regarded as tantamount to a creditor's claim. Cf. Haley v. United States, 46 F. Supp. 4 (D. Mont. 1942), modified, 145 F.2d 235 (9th Cir. 1944) (earlier veterans' insurance). 
them, a totally incongruous result of allowing the wife a windfall because of the fortuity of intestacy would follow the allowance of her claim under section 201.88 The complementary argument is that since the husband possessed all the indicia of separate ownership, the proceeds which he ordered paid to his estate perforce should retain that character. ${ }^{39}$

Although this line of reasoning is not inconsistent with the holding in Allie, it overlooks the fact that the court's reasoning there was based on an initial determination that Wissner should not be read as holding that the federal law governing NSLI had completely superseded local laws. ${ }^{40}$ The sigmificance of Allie. it is submitted, lies in the implication of the broader proposition that a NSLI policy will be treated like an ordinary commercial policy, to the extent that it may be controlled fully by local laws, in any situation in which the governing federal law does not specifically direct otherwise. Thus, in the suppositious situation under consideration, it would seem that the requirements of federal law are met by payment to the insured's estate, for he has expressed no other distributive intent needful of federal protection. The better argunient, it seems, is that the NSLI policy nuay be treated as having been community property all along, except for the specific conditions imposed by federal law. These conditions have been satisfied and no obstacle remains for the wife to surmount in her effort to take the proceeds as community property under section 201 .

A similar, and more probable, situation would arise where the insured designates his wife as beneficiary of a NSLI policy but does not give her the option of selecting a lunip sum settlement. If he predeceases her intestate and she subsequently dies before receiving all of the installments due and payable, the remainder will be paid in a lump sum to the husband's estate, regardless of the circumstances of the wife's death. ${ }^{41}$ Could the wife's estate then clain the "after-acquired" residue of the proceeds as community property? Again, the wife survived the husband so her estate inust take under section 201. The same arguments regarding classification considered above could be urged here. In addition, substantial analytical support for the contention that the NSLI policy and proceeds are community property except for federal law himitations may be found in Estate of Perryman. ${ }^{42}$ There the California district court of appeal considered a case which, though it involved Civil Service Retirement funds, presented nearly identical facts. There it was urged that Wissner compelled the conclusion that the remainder

38 Were this argument valid she would take as an heir only that share of her husband's separate property as allowed by CAL. PROB. CODE $§ \S 220-21,223-24$.

39 It could be urged that the insured's designation of his estate is tantamount to a designation of his separate property heirs as named NSLI policy beneficiaries, and, as such, should receive similar protection under the Wissner doctrine from community property claims. It would seem that such a construction, though perhaps refecting the insured's true intention in some instances, would be based on grounds too conjectural to be persuasive against treating proceeds as community property whenever federal law does not directly specify otherwise.

40 The decedent's heir in Allie, claiming all under $\$ 225$, contended that the predeceased husband's heirs could not stand on $\$ 228$ since they had not sustained the burden of proving a prior community nature of the proceeds (see note 12 supra, item (1)). He urged that Wissner precluded the wife from ever acquiring NSLI proceeds as community property, so the husband's heirs should have no greater rights now than she had during marriage. Respondent's Petition for a Hearing, p. 8. An imphed premise of this argument, however, is that Wissner makes a NSLI policy the husband's separate property. Since proceeds are traceable to this property character, a logical conclusion of his reasoning is that $\S 229$ is applicable and he should take none instead of at least one-half of the proceeds. That such an absurd result is not unlikely demonstrates the practical unsoundness of arbitrarily relying on Wissner when local laws do not directly conflict with the specific mandate of that case.

41 See note 27 supra, item (3).

42133 Cal. App. 2 d 1, 283 P.2d 298 (1955). 
of the fund paid to his estate was the husband's separate property and must be so distributed. The court noted that nothing in the act indicated a congressional intent to restrict distribution by the husband's administrator, and therefore an application of community property laws would not conflict with federal law. The court concluded by distributing the fund to the wife's executrix under section 201 pursuant to the California rule that retirement funds are community property. ${ }^{43}$

It is submitted that the theory of the Perryman case is implicit in Allie; the pervasive theme in each case seems to be that the property riglits of California citizens ought to be determined by California community property laws whenever possible. ${ }^{4}$ This theory leads to the conclusion that NSLI should be regarded as being sui generis only when federal law expressly requires. ${ }^{45}$

Furthermore, it appears that there is a real question whetler Wissner, which construed the pre-1946 NSLI Act to deny the wife a direct community property interest, now accurately reflects the intent of Congress as to the statute enacting post-war NSLI. It will be recalled that the act underwent a substantial metamorphosis after World War II. It was then intended that NSLI for veterans should be brought in line, in most respects, with commercial insurance. ${ }^{46}$ Though a bargain, NSLI is by no means a gratuity as are some non-contributing "pensions." high to deny to the wife the value of a community investment in other insurance.48

43 It seems that the similarity between Wissner and Perryman ends here. It is questionable whether Wissner necessarily compels the conclusion that in every case where a federal statute confers upon her busband the right to designate and change beneficiaries, a priori a wife must be denied community property rights. The dominant feature of the Wissner case was the paternal relationship between the Government and its fightingman, with respect to which tho need for a uniform application of the federal enactinent outweighed the vagaries of local law. See 338 U.S. 655, 658 (1950). It seems that each federal statute pursuant to which funds are disbursed ought to be analyzed thoroughly for congressional intent before a purpose to forestall comnuunity property interests is divined from the letter of the law. Military pay was held to be community property. French v. French, 17 Cal. 2d 775, 112 P.2d 235 (1941). But see Wissner v. Wissner, supra at $657, \mathrm{n} .2$ (possibly casting doubt on the French case).

44 The foundation of the marital property system of California lies in the residual nature of CaI. CIv. CODE $\& 164$. The basic presumption is that if property is not otherwise specifically classifiable, it is community property.

45 The marital property nature of cash surrender, dividend (see 38 U.S.C.A. $\$ 706$ (Supp. 1959)) and Total Disability Income receipts (38 U.S.C.A. $\$ 715$ (Supp. 1959) (benefits of $\$ 10.00 / \mathrm{mo} . / \$ 1,000.00$ of insurance payable on disability at added premium cost)) is still in doubt. It has been suggested that a wife always could recoup her community interest in premiums out of NSLI proceeds. See Wissner v. Wissner, 338 U.S. 655, 658 (1950). Accordingly, she might acquire a right to a portion of cash surrender funds, irrespective of the husband's wish or attempt to deny it, smce surrender value normally represents premiun reserve plus accrued dividends.

NSLI dividends are not gratuities but are shares in the surplus of the participating funds, representing, in a sense, a return on invested capital. See 1956 VA Report, op. cit. supra note 4, at 130. However, NSLI dividends have been held exempt from taxation and creditors' claims. (The exemption section is discussed at note 32 supra.) See In re Walker, 94 F. Supp. 49, 51-52 (N.D. Ohio 1950). If the wife still is held to come withm the prohibition of the exemption section her claim to dividends also might be defeated.

46 See 1956 NSLI Hearings, passin. Op. cit.supra note 19. See particularly the testimony of Mr. Harold W. Breining, Assistant Administrator in charge of Insurance, id. at 73-74: "But now, for practical purposes, [NSLI] . . . will be on a self-sustaining basis, no different from any other mutual company, and we feel we should follow their practices."

47 Some servicemen's pensions are considered gratuities in which no rights "vest." Turner v. United States, 237 F.2d 700, 703 (8th Cir. 1956) (construing Korean War Free Indemnity Insurance). To be distinguished are pensions which represent deferred wages. $C f$. Boyd v. Curran, 166 F. Supp. 193, 198-99 (S.D.N.Y. 1958).

48 The annual premium for a $\$ 10,000$ NSLI Ordinary Life policy, begun at age 25 , and authorized to issue prior to April 25,1951 , is $\$ 162.20$ (less dividends). KMMBrougr \& GLEN, 
NSLI is below commercial rates principally because the Government pays the administration costs and costs incurred due to war-hazard liabilities, the latter being neghigible during peacetime. ${ }^{49}$ The participating fund is otherwise selfsustaining for all peacetine risks in a manner similar to that of any commercial nutual fund..$^{50}$

Two of the three NSLI provisions deemed controlling in Wissner are still in the act, but are not in theniselves unique or expressly exclusive of the wife's rights. A similar revocable beneficiary provision is to be found in nearly every nodern commercial policy. ${ }^{51}$ That the husband is given this right or power seems irrelevant to the issue of the wife's rights. Since a wife claims an interest only as an owner of community property, not as a holder of a beneficiary's "expectancy," it follows that if her husband designates a third party, she must take either notwithstanding this provision or not at all. ${ }^{52}$ Every state has a statute exempting insurance avails from execution or sinilar "seizure." between a wife's assertion of a community property ownership right and a creditor's claim seems to have hittle to commend it. The allowance in 1946 of "vested rights," while perhaps also enhancing her standing to raise a due process issue, is inore significant as a removal of one important inpediment to the wife's claim as an owner. On balance, it appears that Congress would include these provisions as a matter of course in any commercial-type life insurance scheme adopted for veterans, irrespective of an intent to rule out cominunity property rights.

These considerations are more significant when viewed in a peacetime setting removed from the emergency of war and respecting the veteran-civilian rather than the servicenan. Doubtless a uniform and paternalistic application of laws was essential to the relationship of the Sovereign and its fighting man during the war. It would seem equally clear that the importance of those aspects is greatly diminished in the context of the Sovereign and the average veteran, to the extent, at least, that the latter's morale and well-being are today so needful of protection against his own state's basic property system..$^{54}$ However, aside from whether it ought to be Congress's policy to preclude community property rights in NSLI, it is submitted that such a purpose does not in fact exist with regard to post-war NSLI, and that Wissner ultimately should be limited to its original fact situation.

\section{Richard Alexander Burt*}

op. cit. supra note $26, \S 548$, at 421 . Total Disability covernge would add $\$ 24.90$ per year. Id. $\S 548$, at 425 .

\$9 See 38 U.S.C.A. $\$ 721$ (a) (Supp. 1959), for NSLI. Extra-hazard mortalities represented $21 / 2 \%$ of actual deaths in fiscal year 1956. 1956 VA Report, op. cit. supra note 4, at 127 . Brolser's coinmissions and other incidental costs are saved.

50 Each of the four veterans' insurance schemes has its own fund which is administered Iike a "separate insurance company." Ibid. See note 4 supra.

31 VANCE, INSURANCE 674-75 (3d ed. 1951).

52 See note 5 supra and accompanying text.

53 VaNCE, op. cit. supra note 51, at 741. See Car. Code Civ. Proc. \$§ 690, 690.19. Alimony claims have been held to transcend the public policy respecting the exemption statutes. Schlacfer v. Schlaefer, 112 F.2d 177 (D.C. Cir. 1940); In re Bagnall's Guardianship, 238 Iowa 905, 29 N.W.2d 597 (1947). Wissner distinguished these cases on the ground that a property claim does not involve the transcendant moral obligation associated with alimony. 338 U.S. 655, 659-60 (1950). On the other hand, Heifner v. Soderstrom, 134 F. Supp. 174 (N.D. Iowa 1955), purporting to deal with an alimony award of a Cahifornia court, distinguished the Schlaefer and Bagnall cases on the grounds that Wissner had distinguished them and that they had not involved NSLI but other federal funds. It seems this circular reasoning demonstrates the unsoundness of basing a line of reasoning leading to a preclusion of community property rights on a mere creditor exemption section.

54 See Mr. Justice Minton's dissent in Wissner v. Wissner, 338 U.S. 655, 663-64 (1950). 